\title{
Changes in physiological and immunological parameters during the peripartum period in Zerasca sheep
}

\author{
L. Giuliotti ${ }^{1}$, O. Lai ${ }^{2}$, R. Cavallina ${ }^{2}$, L. Alfieri ${ }^{2}$, G. Rabusca ${ }^{3}$, M.N. Benvenuti ${ }^{1}$ \\ ${ }^{1}$ Department of Veterinary Science, University of Pisa - 56124, Pisa (PI), Italy \\ ${ }^{2}$ IZS Lazio and Toscana - 00178 Roma (RM), Italy \\ ${ }^{3}$ Veterinary practitioner -54027 Pontremoli (MS)
}

\begin{abstract}
The aim of this study was to provide the picture of the dynamics of some blood parameters in the native Zerasca sheep breed during the peripartum period. Blood samples were collected from peripheral blood of 14 ewes at different times: from $21 \mathrm{~d}$ before lambing to $42 \mathrm{~d}$ after. Physiological and immunological parameters were evaluated: aspartate-aminotransferase, creatine kinase, lactate dehydrogenase, non-esterified fatty acids, total protein, total antioxidant capacity, free radicals, serum bactericidal activity and serum lysozyme. One-way repeated measures ANOVA test was performed. Results showed a significant influence of the peripartum and the deviation from the normal range on many parameters.
\end{abstract}

Key words: sheep, lambing, peripartum, biochemical parameters, immunological parameters

\section{Introduction}

Last pregnancy and lactation represent critical phases causing changes and adaptation in metabolism (Piccione et al. 2009) and in immune responsiveness (Lacetera et al. 2004).

Since there is not a great availability of this kind of information on meat sheep breed the aim of this study was to investigate the influence of the periods around lambing on some physiological and immunological parameters in an Italian native meat sheep breed.

\section{Materials and Methods}

The experiment was performed in accordance with the European Union directive 86/609/EEC regarding animal care. The study was carried out in a farm of Zerasca ewes, a native breed of endangered status, located in the Zeri district (Massa Carrara, Italy) at an altitude of $800 \mathrm{~m}$ a.s.l. Animals are raised almost all year round on open pastures. Fourteen pluriparous and clinically healthy ewes, reared in natural condition were randomly selected. From the jugular vein, 56 blood samples were collected in the morning, in tubes with K3-EDTA and without. Four blood samplings were performed according to the following scheme 1 .

Correspondence to: L. Giuliotti, e-mail: lorella.giuliotti@unipi.it, tel: +39502216892 


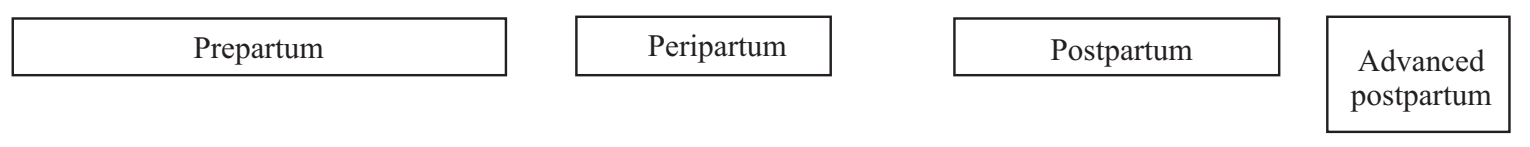

\begin{tabular}{lllllllllllllll}
\hline-7 & -6 & -5 & -4 & -3 & -2 & -1 & 0 & 1 & 2 & 3 & 4 & 5 & 6 & 7 \\
& & \multicolumn{8}{c}{ Experimental weeks }
\end{tabular}

Scheme 1. Samling time.

Table 1. Trend of the examined parameters with relation to the period around lambing.

\begin{tabular}{|c|c|c|c|c|c|c|c|c|c|c|c|}
\hline & \multirow{2}{*}{$\begin{array}{l}\text { Normal } \\
\text { range }\end{array}$} & \multirow{2}{*}{ UM } & \multicolumn{2}{|c|}{ Prepartum } & \multicolumn{2}{|c|}{ Peripartum } & \multicolumn{2}{|c|}{ Postpartum } & \multicolumn{2}{|c|}{ Advanced postpartum } & \multirow{2}{*}{$\mathrm{P}$} \\
\hline & & & mean & SE & mean & $\mathrm{SE}$ & mean & $\mathrm{SE}$ & mean & $\mathrm{SE}$ & \\
\hline AST & $40-123$ & $\mathrm{U} / \mathrm{L}$ & $88.00^{\mathrm{A}}$ & 3.973 & $94.87^{\mathrm{A}}$ & 3.869 & $111.14^{\mathrm{B}}$ & 3.973 & $140.80^{\mathrm{BC} \uparrow}$ & 4.910 & $* *$ \\
\hline $\mathrm{LDH}$ & $<530$ & $\mathrm{U} / \mathrm{L}$ & $432.86^{\mathrm{A}}$ & 12.639 & $506.29^{\mathrm{B}}$ & 11.685 & $507.57^{\mathrm{B}}$ & 12.639 & $502.20^{\mathrm{B}}$ & 15.567 & $* *$ \\
\hline NEFA & $102-450$ & $\mu \mathrm{moli} / \mathrm{L}$ & $934.29^{\mathrm{B} \uparrow}$ & 98.073 & $459.75^{\mathrm{A} \uparrow}$ & 95.503 & $278.14^{\mathrm{A}}$ & 98.073 & $371.40^{\mathrm{A}}$ & 121.214 & $* *$ \\
\hline $\mathrm{TP}$ & $6-7.9$ & $\mathrm{~g} / \mathrm{dl}$ & $6.71^{\mathrm{A}}$ & 0.111 & $6.79^{\mathrm{A}}$ & 0.102 & $7.41^{\mathrm{B}}$ & 0.111 & $7.53^{\mathrm{B}}$ & 0.128 & $* *$ \\
\hline $\mathrm{CK}$ & $<130$ & $\mathrm{U} / \mathrm{L}$ & $161.93 \uparrow$ & 32.033 & $252.50 \uparrow$ & 31.194 & $190.93 \uparrow$ & 32.033 & $181.70 \uparrow$ & 39.592 & NS \\
\hline TAOC & $200-300$ & $\mu \mathrm{g} / \mathrm{dl}$ & $334.79^{\mathrm{A} \uparrow}$ & 10.857 & $358.53^{\mathrm{A} \uparrow}$ & 10.038 & $340.00^{\mathrm{A} \uparrow}$ & 10.857 & $393.73^{\mathrm{B} \uparrow}$ & 12.603 & $* *$ \\
\hline OFR & 44-88 & U/Carr & $76.07^{\text {Aa }}$ & 9.500 & $107.87^{\mathrm{b} \uparrow}$ & 9.251 & $116.43^{\mathrm{B} \uparrow}$ & 9.500 & $129.30^{\mathrm{Bc} \uparrow}$ & 11.741 & $* *$ \\
\hline $\mathrm{SL}$ & $1-3$ & $\mu \mathrm{g} / \mathrm{dl}$ & $3.28^{\mathrm{B} \uparrow}$ & 0.408 & $2.11^{\mathrm{Bb}}$ & 0.377 & $1.14^{\mathrm{Aa}}$ & 0.408 & $0.27^{\mathrm{A}} \downarrow$ & 0.473 & $* *$ \\
\hline SBA & $>90$ & $\%$ & $80.64 \downarrow$ & 2.625 & $78.44 \downarrow$ & 2.543 & $78.50 \downarrow$ & 2.625 & $74.64 \downarrow$ & 3.049 & NS \\
\hline
\end{tabular}

**: P $\leq 0,001$; NS: not significant; $\uparrow$ values over the threshold of the normal range; $\downarrow$ values under the threshold of the normal range.

Means followed by lowercase letters were significantly different: $p \leq 0.05$. Means followed by capital letters were significantly different: $\mathrm{p} \leq 0.01$.

Aspartate-aminotransferase (AST), lactate dehydrogenase (LDH), non-esterified fatty acids (NEFA), total proteins (TP), creatine kinase (CK), were measured by an automatic biochemical analyser (Olympus AU 400). Total antioxidant capacity (TAOC) and oxygen free radicals (OFR) were monitored by a colorimetric method (DIACRON). Lysozyme (SL) and bactericidal activity (SBA) determinations were performed by bacteriological assay (Osserman and Lawlor 1966, Amadori at al. 2002). One-way repeated measures ANOVA test was performed. Statistical analysis was performed by JMP (SAS Institute 2002).

\section{Results and Discussion}

Values of each parameter during the sampling period and their normal range are illustrated in Table 1 . The period around lambing significantly affected several physiological and immunological parameters.

The trend of AST showed a significant increase in the postpartum exceeding the normal range in the last sampling, whereas LDH displayed a fluctuating trend with significant variation: this trend would suggest an overloading of liver functionality as already observed in ewes by El-Sherif and Assad (2001). NEFA was significantly affected by the physiological phase and exceeded the normal range in the prepartum and in the peripartum; high nutritional requirements during the last weeks of pregnancy and the decrease of voluntary feed intake during late pregnancy might mobilize body reserves resulting in NEFA release into the bloodstream (Joy et al. 2014). A significant increase in TP values were observed in the postpartum in accordance with Piccione et al. (2009). CK exceeded the normal range in each sampling, indicating a muscle effort, probably linked to the grazing activity on sloping ground. TAOC significantly increased in the advanced postpartum showing values over the normal range in each sampling, this trend could indicate an oxidative stress as previously reported in the peripartum by Celi et al. (2010). After lambing, a significant and progressive increase of OFR occurred as it appears within the normal range only in the prepartum. The farming system and the rusticity of the Zerasca sheep likely make rare the occurrence of conditioned diseases, therefore the oxidative stress is rather induced from lambing and lactation. SL constantly decreased, showing extremes out of the normal range; regarding this parameter, inter-breed differences in sheep values were found (Sotirov et al. 2005). SBA was always under the normal range indicating a restricted innate immunity capacity.

The study evidenced that the peripartum signifi- 
cantly affected many biochemical and immune parameters, often inducing deviations from the normal range. Furthermore, results pointed out the sensibility of the Zerasca breed in the peripartum, suggesting the need of a proper management of sheep especially in terms of feeding.

\section{References}

Amadori M, Archetti IL, Mondelli MM, Fazia M (2002) Animal welfare assesment. Quaderni Fondazione Iniziative Zooprofilattiche e Zootecniche 51: 51-54.

Celi P, Di Trana A, Claps S (2010) Effects of plane of nutrition on oxidative stress in goats during the peripartum period. Vet J 184: 95-99.

El-Sherif MM, Assad F (2001) Changes in some blood constituents of Barki ewes during under pregnancy and lactation under semi arid conditions. Small Ruminant Res 40: 269-277.
Joy M, Ripoll-Bosch R, Sanz A, Molino F, Blasco I, Álvarez-Rodríguez J (2014) Effects of concentrate supplementation on forage intake, metabolic profile and milk fatty acid composition of unselected ewes raising lambs. Anim Feed Sci Tech 187: 19-29.

Lacetera N, Bernabucci U, Nardone A, Ronchi B (2004) Immunological parameters in periparturient sheep. J Anim Feed Sci 13 (Suppl 1): 601-604.

Osserman EF, Lawlor DP (1966) Serum and urinary lysozyme (muramidase) in monocytic and monomyelocytic leukemia. J Exp Med 124: 921-952.

Piccione G, Caola G, Giannetto C, Grasso F, Calanni Runzo S, Zumbo A, Pennisi P (2009) Selected biochemical serum parameters in ewes during pregnancy, post-parturition, lactation and dry period. Anim Sci Pap Rep 27: 321-330.

SAS (2002) JMP statistical discovery software, Version 5. SAS Institute Inc., Ed. Cary, NC, USA.

Sotirov L, Dimitrov I, Djorbineva M (2005) Serum lysozyme concentrations in different sheep breeds. Bulg J Vet Med 8: 83-89. 